\title{
Entrepreneurial Skill Development in Disadvantaged Group of Entrepreneurs
}

\author{
V. R. Palanivelu, N. Chandrasekar
}

\begin{abstract}
Entrepreneurship is considered as a panacea to socioeconomic problems. Small enterprises not only provide self-employment, but help in correcting regional disparities and more equal distributions of wealth. Entrepreneurship development among weaker sections, that is scheduled casts and scheduled tribes, is the need of the hour in the present context of privatization. The disinvestment polices of the government had adverse effect on generations of employment opportunities in the public sector. Obviously, the most affected people are from scheduled castes, scheduled tribes, and other backward casts for which there are reservations in government jobs. The socioeconomic backwardness of scheduled castes and tribes, VJNT/NT, other backward classes and ultra poor from upper classes can be found in their dependence on agriculture, illiteracy, lower awareness levels, incidence of poverty, and underemployment. I attempted to probe into the research question such as whether there is an association between demographic characteristic and entrepreneurship development of people from marginalized groups. The study interfered that there was an association between gender, social status, marital status, education, occupational backgrounds, entrepreneurship development programmed except age of the respondents. The study suggested that special EDPs should be framed to train various group of entrepreneurs. In addition, necessary support of finance, infrastructure, and marketing should be extended to the entrepreneurs adequately and timely.
\end{abstract}

Keywords: Occupational Mobility, Demographic Characteristics Entrepreneurial Skills, Self Employment.

\section{INTRODUCTION}

The social environment in India has been enhancing gradually. Spread of education, industrialization, reservation policy, legal protection, and democratic values etc. are the factors instrumental for enhanced social and occupational mobility of disadvantaged groups in India. Research studies have shown that environmental skill development depends on the factors such as, family background, occupation, assets, money, sex, education, knowledge, and caste. In order to understand the level of skill development among the respondents, the responses were collected regarding the entrepreneurial skills, that is, creative thinking, business planning, decision making, organization, communication and team building, risk management, adaptability, resources

Revised Manuscript Received on December 05, 2019.

* Correspondence Author

Dr. V. R. Palanivelu*, Professor-Cum-Director (i/c), Periyar Institute of Management Studies(PRIMS), Periyar University, Salem, Tamil Nadu, India.

N. Chandrasekar, Research Scholar, Manonmaniam Sundaranar University, Abishekapatti, Tirunelveli, Tamil Nadu, India. Email: n_chandru@rediffmail.com management, and marketing.

\section{REVIEW OF LITERATURE}

A few research studies have been conducted on entrepreneurship development of groups in India. Some of the earlier research studies have found association between demographic variables and entrepreneurial skill development. Occupational background of a person has a deep impact on entrepreneurship development.

Yale (1954) explained that social marginality promotes entrepreneurship among individuals or groups. Sadana and Thorat(2009) observed that the restriction on the ownership of property rights in the past had resulted in a large proportion of low caste persons remaining without capital assets. Deshpande and Sharma (2013) argued that certain castes and communities have traditionally been business communities, and entrepreneurs from these communities members start with clear natural advantages of available knowledge, know-how and strong business networks passed down through the generations. Sambasivaiah, Rajaiah, and Sivasankar (2018) investigated the impact of socioeconomic factors on entrepreneurship development and pointed out that the growth of entrepreneurship had more or less been influenced by the factors like previous experience, strong desire to do something, independent in life and motivation by the family. Aaijaz, Ibrahim, and Ahmad (2019) inferred in their study that made female respondents were equally Interested in becoming entrepreneurs. Rao and Suri Ganesh (2019) Suggested that women should be provided with adequate training in developing entrepreneurial skills.

\section{STATEMENT OF THE PROBLEM}

Entrepreneurship development among weaker section people having no-business background is a new area of research. There has been a phenomenal growth in micro enterprices run by self-help groups of poor members. In recent years, artisans, craftsmen, farmers, and unemployed people belonging to the lower strata of the society, that is SC, ST, and other backward class people are joining entrepreneurship. I intended to probe into the research questions as to understand the entrepreneurial skills developed among the sample entrepreneurs and find out the association between demographic characteristics and entrepreneurial skills development of the sample entrepreneurs. 


\section{OBJECTIVES OF THE STUDY}

1. To identify the association between demographic variables and entrepreneurship development among the disadvantaged group entrepreneurs.

2. The study attempted to focus on the development of entrepreneurship among the disadvantaged group people with no background of business.

3. The study examined as to how demographic characteristics, that is age, education, marital status, social status, and occupational background of entrepreneurs and their entrepreneurial skills development are associated.

\section{RESEARCH METHODOLOGY}

Data Sources: The study is based on both types of data, that is primary data and secondary data. The primary data were collected by requesting the respondents to participate in the study by filling up the questionnaires and partly from the interactions with respondents. The secondary data were collected from reports, books, and journals. The data were systematically compiled, tabulated, and analysed with tools such as simple percentage analysis.

\section{RESULTS AND DISCUSSION}

Table - 1: Demographic Profile of Disadvantaged Group Entrepreneurs

\begin{tabular}{|c|c|c|c|}
\hline $\begin{array}{l}\text { SI. } \\
\text { No. }\end{array}$ & Demographic variables & $\begin{array}{c}\text { No. of } \\
\text { Respondents }\end{array}$ & $\%$ \\
\hline \multicolumn{4}{|c|}{ Age (in Years) } \\
\hline 1 & Up to 25 & 72 & $\begin{array}{c}11.4 \\
4\end{array}$ \\
\hline 2 & $25-35$ & 280 & $\begin{array}{c}44.5 \\
1\end{array}$ \\
\hline 3 & $35-45$ & 199 & $\begin{array}{c}31.6 \\
3\end{array}$ \\
\hline 4 & $45-55$ & 59 & 9.37 \\
\hline 5 & Above 55 & 19 & 3.02 \\
\hline & Total & 629 & 100 \\
\hline \multicolumn{4}{|c|}{ Gender } \\
\hline 1 & Male & 521 & $\begin{array}{c}82.8 \\
2\end{array}$ \\
\hline 2 & Female & 108 & $\begin{array}{c}17.1 \\
7\end{array}$ \\
\hline & Total & 629 & 100 \\
\hline \multicolumn{4}{|c|}{ Marital status } \\
\hline 1 & Married & 476 & $\begin{array}{c}75.6 \\
7\end{array}$ \\
\hline 2 & Un married & 117 & $\begin{array}{c}18.6 \\
0\end{array}$ \\
\hline 3 & Divorced & 19 & 3.02 \\
\hline 4 & Separated & 17 & 2.70 \\
\hline & Total & 629 & 100 \\
\hline \multicolumn{4}{|c|}{ Education } \\
\hline 1 & Illiterate & 25 & 3.97 \\
\hline 2 & Primary & 36 & 5.72 \\
\hline 3 & Secondary & 81 & $\begin{array}{c}12.8 \\
7\end{array}$ \\
\hline
\end{tabular}

\begin{tabular}{|c|l|c|c|}
\hline 4 & Higher secondary & 272 & $\begin{array}{c}43.2 \\
4\end{array}$ \\
\hline 5 & Graduation & 157 & $\begin{array}{c}24.9 \\
6\end{array}$ \\
\hline 6 & Post graduation & 45 & 7.15 \\
\hline 7 & Technical-ITI/polytechnic & 13 & 2.06 \\
\hline \multicolumn{1}{|c|}{ Total } & 629 & 100 \\
\hline Occupation & Agriculture & 289 & $\begin{array}{c}45.9 \\
4\end{array}$ \\
\hline 1 & Agriculture labor & 165 & 26.2 \\
3
\end{tabular}

The study attempts to understand the demographic characteristics, like age, gender, education, caste, occupational background, and income of the sample of entrepreneurs that is 629 in 12 districts Madurai, Trichirappalli, Salem, Virudhunagar, Tirunelveli, Sivaganga, Ramand, Pudukottai, Erode, Dindigul, Namakkal and Thirupur Districts in Tamil Nadu. The data were based upon the responses collected through a structured questionnaire and partly interviews with the respondents. The research studies have suggested that demographic characteristics and entrepreneurship have a strong association. The study focused on understanding the demographic Characteristics and their association with entrepreneurial skill development levels of the respondents.

The above table- 1 indicates that out of 629 respondents in case of age up to 25 years(11.44\%), 25-35 Years (44.51\%), $35-45$ Years(31.63\%), 45-55 Years(9.37\%), above 55 Years (3.02\%). The most of the respondents are in 25-35 Years. In Gender division of the respondents, Male respondents are $82.82 \%$ and female Respondents are $17.17 \%$. In case of marital status $75.67 \%$ of the respondents are married persons. In case of educational status $43.24 \%$ of respondents are having their educational status is higher secondary level. But in case of occupation of the respondents $45.94 \%$ of the respondents are doing their occupation in Agriculture.

\section{CONCLUSION}

The major conclusion of the study is that there is a significant association between demographic characteristics such as, gender, education, social status, occupational background, and marital status and entrepreneurial skill development of disadvantaged group entrepreneurs. However, the study found no significant association between the various demographic variables. Entrepreneurship development programmes have a deep impact on the entrepreneurship development process. The special EDPs should be framed to train disadvantaged group entrepreneurs. In addition, necessary support of finance,

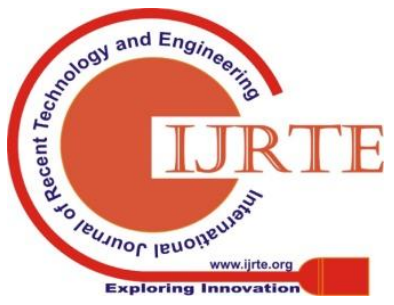


infrastructure, and marketing should be extended to the entrepreneurs adequately and timely.

In spite of the policy measures and welfare schemes. They are coming up from socio-economically disadvantaged groups having more or less access to the resources. Therefore, it is the need of the hour to create a conducive socioeconomic environment to enhance the participation of disadvantaged groups in the business sector. In this regard, it is suggested that financial inclusion programmed should be implemented effectively, every person irrespective of caste, creed, and religion must have easy access to financial services and basic facilities required for starting ventures should be provided promptly by the concerned agencies.

\section{REFERENCES}

1. Kamble, C.B.,\& mahajan, S.S.(2014). Entrepreunership developmen among scheduled castes

2. beneficiaries in kolhapur district. Internalional journal of advance and applied research ,1(5),

3. 9-15.

4. David, B.A., Werner,\&jagannadha,P.T.(2016).Religion and entrepreunership.max plank

5. institute of economic, entrepreunership, growth and public policy group ,kachlaiche,

6. germany, 1-27.

7. Haynes, P.J.(2015).differnces among entrepreuners :are you experienced? International

8. jouenal of entrepreunerial behaviour and research,9(3),111-128.

9. Awasthi, D.N.,\&Sebastian J.(2016).Evaluation of entrepreneurship development programmes,

10. New delhi, India: sage publications.

11. Aaijaz, N., Ibrahim,D.B.,\& ahamed ,G.(2017). From the learners to entrepreuners: A study on

12. the inclination of university students towards entrepreneurship as a carrier option and the role

13. of education. Prabandhan: Indian journal of management, 5(9),

14. 4-18.DOI:10.17010/pijom/2012/v5i9/60249.

15. Iyer,L., khanna, T.,\&varshney,A.(2019,February 9). Caste and entrepreunership in india.

16. Economic \& political weekly,48(6),52-60.

\section{AUTHORS PROFILE}

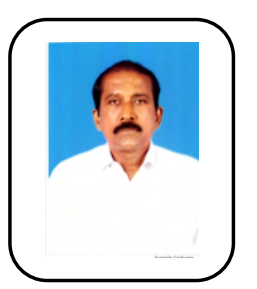

Dr. V. R. Palanivelu, obtained his post graduate degree in commerce from University of Madras and M.Phil from Madurai Kamaraj University and Master degree in Business Administration from University of Madras. Presently he is working as Professor \& Head in the Department of Management Studies at Periyar University, Salem, Tamil Nadu. He has more than 23 years of experience in teaching and research. He published four books and more than 60 articles at various international journals. Presently he is the chairman of Board of Studies in the post graduate courses of the Business Administration. He is the Senate member of Periyar University. He is the member of Board of Studies in Business Administration at various universities and colleges. He organized 4 International Conferences, 10 workshops and various Entrepreneurship related programs. He is the Co-Ordinator of Export Promotion Cell of Periyar University. He guided $10 \mathrm{Ph} . \mathrm{D}$ candidates. He is the Chairman of Question Paper Setting Board at various universities. He visited some foreign countries. He presented paper at various National and International level Conference.

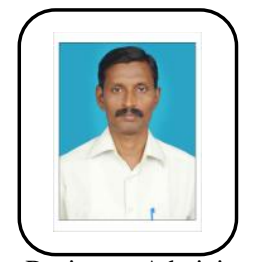

Mr. N. Chandrasekar, obtained his post graduation in Business Administration from Madurai Kamaraj University and M.Phil from Alagappa University. Presently he is working as Associate Professor in the Department of Management Sciences, Thiruthangal Nadar college, Selavayal, Chennai affiliated to the University of Madras. He has 16 Years of experience in teaching and providing guidance for Post Graduation in Business Administration from Madurai Kamaraj University, Alagappa University, Indra Gandhi National open University and University of Madras.
He published more than 7 Articles in various journals from National level and International level. He has 15 Papers presented and Participated from various University and Colleges from in around Tamil Nadu. He has got Best Teacher Award from Thiruvalluvar Thiruchabai, K.K.D.Nagar, Chennai. He is the External Question Setter in Ramakrishna Mission Vevekananda College, (Autonomous), Mylopore, Chennai,Vellaichaamy Nadar College (Autonomous), Madurai and Dr.B.R.Ambedkar Govt. Arts College for Men (Autonomous), Vyasarpadi, Chennai. He is in Board of Studies Member for Department of Business Administration, Sacred Heart College (Autonomous), Tirupatore, Vellore District. He has Submitted his Ph.D Thesis in Business Administration discipline in Manonmaniam Sundaranar University, Tirunelveli, Tamil Nadu.. 